\title{
Mexican-Origin Women's Employment Instability
}

by Roberto M. De Anda

University of Illinois, Urbana-Champaign

Working Paper No. 51

October 2000 



\title{
Mexican-Origin Women's Employment Instability
}

\author{
by Roberto M. De Anda \\ University of Illinois, Urbana-Champaign
}

Working Paper No. 51

October 2000

\begin{abstract}
:
This study compares the causes and consequences of employment instability among Mexican-origin women, White women, and White men. Data for the analysis comes from the work experience supplement in the March 1995 file of the Current Population Survey (CPS). The supplement documents the respondent's year-long labor force activity. Respondents who had an interruption in employment, or involuntarily worked part-time during the entire year, are said to have experienced employment instability. Using logistic regression, results show that Mexican-origin women with low levels of schooling, immigrants, and those employed in the periphery services sector are highly vulnerable to employment instability. Earnings determination models revealed that employment instability exerts a heavier penalty on Mexican-origin women, compared to their White counterparts, net of human capital endowments and economic sector location.
\end{abstract}

\section{About the Author: Roberto M. De Anda}

Roberto De Anda was born in Tijuana, Mexico, but was raised near San Francisco after his family immigrated to the U.S. He received his B.A. in Chicano Studies from the University of California, Berkeley, and did graduate work in both the U.S. and Mexico; he later earned his M.A. and Ph.D. in sociology from the University of Arizona. Dr. De Anda is an Assistant Professor at the University of Illinois, Urbana-Champaign, where he is a co-founder of the university's Latina/Latino Studies Program. He has published articles on underemployment and is currently investigating the influence of literacy skills on labor market outcomes of minority workers. 



\section{SUGGESTED CITATION}

De Anda, Roberto M. (Ph.D.) “Mexican-Origin Women's Employment Instability,” JSRI Working Paper \#51, The Julian Samora Research Institute, Michigan State University, East Lansing, Michigan, 2000.

The Julian Samora Research Institute is committed to the generation, transmission, and application of knowledge to serve the needs of Latino communities in the Midwest. To this end, it has organized a number of publication initiatives to facilitate the timely dissemination of current research and information relevant to Latinos.

- Research Reports: JSRI's flagship publications for scholars who want a quality publication with more detail than usually allowed in mainstream journals. These are produced in-house. Research Reports are selected for their significant contribution to the knowledge base of Latinos.

- Working Papers: for scholars who want to share their preliminary findings and obtain feedback from others in Latino studies.

- Statistical Briefs/CIFRAS: for the Institute's dissemination of "facts and figures" on Latino issues and conditions. Also designed to address policy questions and to highlight important topics.

- Occasional Papers: for the dissemination of speeches, papers, and practices of value to the Latino community which are not necessarily based on a research project. Examples include historical accounts of people or events, "oral histories," motivational talks, poetry, speeches, technical reports, and related presentations. 



\section{Mexican-Origin Women's Employment Instability}

\section{Table of Contents}

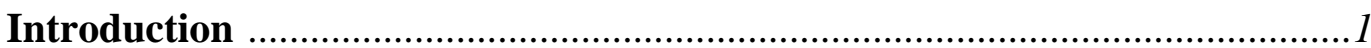

Why Study Employment Instability? …................................................

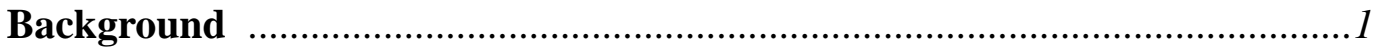

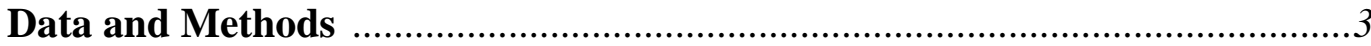

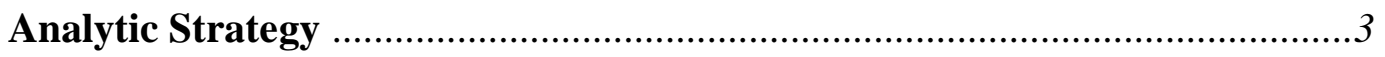

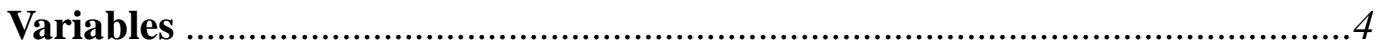

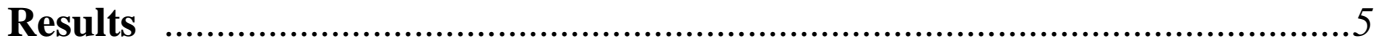

Determinants of Employment Instability ............................................

Employment Instability's Earnings Consequences .....................................

Summary and Discussion

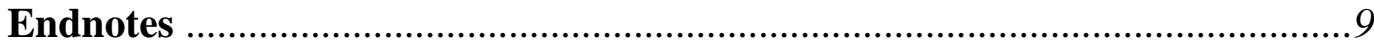

References 



\section{Mexican-Origin Women's Employment Instability}

\section{Introduction}

Although the high unemployment rate of Mexicanorigin women is well-known, our understanding of the causes and consequences of persistent unemployment among them is sketchy. The unemployment rate measures the proportion of persons out of work during a given week - a relatively short period of time. Using a longer time horizon, recent studies suggest that persistent joblessness, or employment instability, is more pervasive than previously thought (Clark and Summers, 1979; Clogg, Eliason, and Wahl, 1990; De Anda, 1991), particularly among minority women (De Anda, 1991; Hsueh and Tienda, 1996; Tienda and Stier, 1996). Research also shows that employment instability - that is, repeated transitions in and out of joblessness - have deleterious earnings consequences (De Anda 1991, 1998; Hsueh and Tienda, 1995). Building on the work of Clogg and his colleagues (1990), this study compares the causes and earning consequences of employment instability among Mexican-origin women, White women, and White men.

\section{Why Study Employment Instability?}

The study of Mexican-origin women's employment instability is important because of their growing presence in the work force. The Latina labor force is projected to grow from 4.8 million in 1994 to about 6.9 million in 2005. This is an increase of $43 \%$ - the greatest increase among all other groups of women or men, excluding Asian and Pacific Islander women (U.S. Department of Labor, 1997).

Studies show that prior work experience is a strong predictor of future labor market outcomes. For example, De Anda (1991), following the approach proposed by Clogg and his colleagues (1990), examined the linkage between prior employment instability and future underemployment among Mexican-origin and White workers. He found that Mexican-origin women who endured employment instability were more prone to experience future underemployment, including joblessness and involuntary part-time work, than their White counterparts. Other studies suggest that persistent employment interruptions may lead to withdrawal from the labor force (e.g., Clark and Summers, 1979).

As Mexican-origin women's work force participation increases, labor-market related earnings become an increasingly important determinant of family economic well-being. With nearly one-fifth of Mexican-origin families headed by women, Mexican families increasingly depend on women's earnings to make ends meet. It is also important to understand the economic contribution of Mexican-origin women, because the high and rising poverty rates of Mexican-origin children (Lichter and Landale, 1995).

The following three questions guide this research:

(1) What is the prevalence of employment instability among Mexican-origin women, White women, and White men?

(2) How do human capital variables (e.g., education), and structural variables (e.g., economic sector location) influence the likelihood of employment instability?

(3) To what extent does employment instability affect annual earnings?

\section{Background}

Previous studies of underemployment measure current labor force status, such as unemployment and involuntary part-time work (De Anda, 1994; Clogg, 1979; Sullivan, 1978; Clogg, Sullivan, and Mutchler, 1986). These studies typically rely on cross-sectional surveys. Although this is an acceptable way to measure labor force status, it captures a relatively short period of time - namely, the activity during the reference week of the survey (i.e., the week prior to the survey). The analysis of a longer time frame would yield a richer portrait of labor force dynamics. To better understand labor force dynamics, Clogg and colleagues took advantage of data in the work experience supplement contained in the Current Population Survey (CPS). Their approach divides the labor force into two major segments of active workers: those who are "stably employed" and those who are "unstably employed." Stably employed workers have continuous employment, whereas unstably employed workers experience discontinuous employment. De Anda (1991) analyzed the association between underemployment and labor force transitions of Mexican-origin workers. His study provided evidence that employment instability was more pronounced among Mexican-origin workers than White workers. He also found that employment instability was detrimental to annual earnings. 
Social scientists have used two major theoretical approaches in their study of labor market stratification: human capital theory and structural approaches.

Human capital theory rests on neoclassical economic assumptions of individual rational behavior and posits that individuals will make investments to improve their skills to enhance future productivity (Becker, 1975). For example, individuals will go to school to improve future economic rewards in the labor market; that is, they expect to earn more. Human capital includes endowments such as education, labor market experience, and immigration.

However, workers' fortunes in the labor market do not depend exclusively on human capital endowments; they are also shaped by their position in the economic structure. To examine the effect of economic sector location on employment instability, Leann Tigges'(1987) approach to economic segmentation was used.

Age. It is important to look at the relationship between age and employment stability because age significantly affects position in the labor market. Typically, young people are found in unfavorable positions in the labor market. As people grow older, their relative status position improves (Clogg, 1979). This can be attributed to the greater resources that adults command. For example, older persons have ostensibly completed their formal schooling, they have gained experience in the world of work and they have acquired more responsibilities such as marriage. Many of these transitions are age specific and play a pivotal role in allocating persons in the socioeconomic structure, including labor force positions. Hence, higher levels of employment instability are expected among the young because they have less experience than older workers and their commitment to the labor force may be limited. Similarly, younger workers tend to earn less than older workers.

Education. Traditionally, education has been viewed as the means to achieve upward social mobility. Education, to be sure, is one of the key variables in studies of social stratification and labor force participation. Researchers have consistently found a positive effect between educational attainment and labor force outcomes such as occupation and earnings (e.g., Blau and Duncan, 1967; Featherman and Hauser, 1978). Although the educational attainment of the Mexican-origin population has appreciably increased in the last few decades, they still lag behind the majority population. The low educational attainment of Mexicans can be attributed, in part, to their disproportionate high school dropout rate. Thus, the schooling gap represents a formidable obstacle to employment for Mexican workers. Low levels of schooling play a critical role in determining low earnings among Mexicans, in increasing their odds of joblessness and in increasing the likelihood of involuntary part-time work. Consequently, higher levels of schooling attenuate the likelihood of employment instability and higher levels of schooling will increase earnings.

Nativity Status. Mexican immigration to the United States has increased recently. Studies have focused on the economic incorporation of immigrants point out that immigrants tend to be employed in the secondary labor market, in jobs that are characterized by their instability in industries subject to increased competitive pressures (Piore, 1979; Portes and Bach, 1985; Morales and Bonilla, 1993). Labor market studies show that Mexican immigrant women are more prone to multiple spells of joblessness and to earn less than their U.S.-born peers (DeFreitas, 1991:133). Therefore, Mexican immigrant women will be adversely affected in the labor market. More specifically, Mexican immigrant women will be more susceptible to employment instability than their U.S.-born peers and immigrants will earn less than those who were born in the United States.

Marital Status. In general, women's labor force activity is different from that of men. Women, especially married women, tend to have more interruptions in labor force participation than men (Polacheck and Siebert, 1993). Such interruptions are likely to produce labor force withdrawal because married women will often attend to family responsibilities (e.g., having and raising children). However, married women who become jobless, but engage in a job search, have a stronger attachment to the labor force than those who completely withdraw from it. The employment trajectories of married women who remain active in the labor force will be more stable than those of unmarried women. Conversely, the earnings of married women are likely to be lower than the earnings of unmarried women.

Economic Sectors. While human capital endowments are important predictors of labor force outcomes, workers' labor market position - i.e., industrial sector location - also matters. Taken together, these factors help explain the divergent patterns of employment instability between Mexican-origin and White women. Studies on economic segmentation show that different industrial segments in the economy yield different labor market returns for workers (e.g., De Anda, 1998). Tigges (1987) found that workers' earnings are sensitive to both how 
production is organized and what is produced. In Tigges' typology, firms in the economy were divided into core and periphery sectors, this dichotomy is based on how production is organized. It is further categorized by what is produced - that is, whether goods or services are produced. Core sector firms are characterized by their large size. In contrast, firms in periphery sectors tend to be small. While firms in core sectors have large assets and profits, periphery sector firms have low assets and profits. Contrary to periphery sector firms, which operate in local and national competitive markets, core sector firms operate in oligopolistic or monopolistic markets that are national and international in scope. Lastly, core sector firms have high levels of unionization and internal labor markets, while periphery sector firms tend to be unorganized and operate in competitive labor markets.

Based on this characterization of firms, Tigges proposed four economic sectors: core transformative, core services, periphery services, and periphery transformative. ${ }^{1}$ Although Tigges does not include the extractive sector in her typology, it is included in this analysis because Mexican-origin workers are overrepresented in this sector. And, employment in this sector is highly seasonal.

The following hypotheses focus on the influence of economic sector location on employment instability:

Hypothesis: Workers employed in the core transformative sector will be vulnerable to employment instability, but they will receive better than average earnings.

Hypothesis: Workers employed in the core services sector will be sheltered from employment instability, and they should get better than average earnings.

Hypothesis: Workers employed in the periphery transformative sector will be vulnerable to employment instability; they will get less than average earnings.

Hypothesis: Employment in the periphery services sector will increase the likelihood of employment instability; it will also provide less than a verage wages.

Hypothesis: Employment in the extractive sector will render workers vulnerable to employment instability; it will provide less than average wages.

\section{Data and Methods}

Data

The annual demographic file of the 1995 CPS provides the data for the analysis (U.S. Bureau of the Census, 1995). This is a nationally representative sample of about 60,000 households, including 2,500 Latino households that are added to improve the representation of this population. Household representatives were asked to identify their race and ethnicity and that of other household members. A respondent is of Mexican origin if the person's origin (ancestry) is Mexican American, Chicano, Mexican, or Mexicano.

In addition to basic socio-demographic information and current labor force status, the annual demographic file includes a work experience supplement. The supplement retrospectively documents respondents'labor force activity during the year preceding the survey. It contains information on respondents' work (e.g., full- or part-time, full- or part-year work) and unemployment experience (e.g., frequency of unemployment episodes).

The sample used in the analysis is limited to Mexican-origin women, White women, and White men aged 16-64 in the experienced, noninstitutionalized labor force. The sample is not restricted to persons who worked continuously during the year prior to the survey. Rather, it includes those whose work histories are punctuated by episodes of unemployment or involuntarily worked parttime for the whole year. These selection criteria yielded a sample of 1,399 Mexican-origin women, of whom 362 were unstably employed.

\section{Analytic Strategy}

The empirical analysis is divided into three parts.

The first part of the analysis compares the prevalence of labor-market types, unstable active and stable active, by selective sociodemographic variables for Mexicanorigin women, White women and White men. Using logistic regression, the second part of the analysis examines the influence of workers' individual attributes (e.g., age, schooling, nativity status and marital status) and economic sector location on the propensity for employment instability. Separate models are estimated for each of the ethnic and gender groups. The outcome variable was coded "1" if the respondent experienced employment instability; " 0 " otherwise. Using ordinary least squares regression (OLS), the last part of the 
analysis estimates the effect of employment instability on annual earnings. The dependent variable is the natural logarithm of annual earnings measured as the total sum of wages, salary, and earnings from self-employment.

\section{Variables}

Construction of the labor-market experience categories, with some exceptions, closely follows the approach proposed by Clogg and his associates (1990). They collapsed their 16 labor-market experience types into a tripartite classification: stable inactive, unstable active and stable active. In this study, the major criterion for selecting the components of labor-market experience focuses on the worktime dimension of economic underemployment (Clogg, 1979). Insofar as available worktime is concerned, if the labor market provides persons with full-time work, then their desire to work a standard workweek is satisfied. However, if they are not working, or are working less than a standard workweek, then their desire to work is not satisfied by the labor market. Thus, workers who experience inadequate hours of work (e.g., unemployment or involuntary part-time work) are included in the unstable active category. Conversely, the stable active category is composed of anyone experiencing adequate hours of work. The stable inactive refers to nonworkers, which resembles persons not in the labor force. This category is excluded from the analysis since these persons neither worked nor engaged in a job search during the preceding year of the survey.

The operationalization of labor-market experience variables strictly adheres to the official definition of labor force concepts used by the Bureau of Labor Statistics. Thus, the unstable active category includes workers who experienced at least one episode of unemployment during the year or year-long, involuntary part-time work. Following the official definition, people are considered unemployed if they are without a job and are actively looking for work. The unstable active category consists of three components: full-time part-year workers looking for work; part-time part-year workers looking for work; and year-long involuntary part-time workers.

Persons are considered full-time workers if they work at least 35 hours per week. Part-year workers are defined as persons who work less than 50 weeks during the year. For part-year workers to be included in the unstably employed category, they must have been engaged in an active job search for at least one week during the preceding calendar year. Involuntary part-time workers are persons whose weekly work schedule falls below 35 hours for reasons beyond their control. The criteria for being counted as an involuntary part-time worker includes two conditions introduced in the CPS in 1994 that were previously assumed: namely, respondents are asked directly if they want and are available for full-time work (see De Anda, 1992; Tilly, 1996). Thus, these labor force states are conceptually similar to economic underemployment.

The stable active category is composed of full-time year-round workers. To be included in this category a person must have worked 35 or more hours per week, at least 50 weeks during the year.

Four categories of education are constructed that closely parallel significant transitions in the schooling process. Schooling categories include respondents with 12 or less years of schooling, those with a high school diploma, those with some college, and those with a college degree. Rather than "years in school completed," these educational categories identify specific degree completion levels.

The nativity status variable is constructed using the following item in the survey: "In what country were you born?" Two categories are created: foreign-born (respondent born in Mexico) and the native-born (respondents born in the United States).

Marital status is recoded into two categories: currently married living with spouse and a residual category. The residual category is composed of "single," "divorced," "widow(er)," or "married, but spouse not living with respondent."

The operationalization of economic sectors follows the typology adapted by Tigges (1987). Relying on this approach, five economic sectors are created: core transformative, periphery transformative, core services, periphery services and extractive. Although Tigges' approach does not include the extractive sector, it is included in this study because workers of Mexican descent are overrepresented in this sector. To define each of these sectors, the three-digit Standard Industry Classification (SIC) codes for respondents' longest job held in the preceding year of the survey are used. 


\section{Results}

\section{Descriptive Analysis}

Table 1 compares the prevalence of labor-market experience types, mean annual earnings and descriptive measures of the explanatory variables used in the multivariate analysis for Mexican-origin women, White women, and White men. As expected, Mexican-origin women experienced the most employment instability: fully one-fourth (25.9\%) were unstably employed. White women were less often unstably employed (17.1\%), while White males were the least frequently unstably employed (14.3\%).

\begin{tabular}{|c|c|c|c|}
\hline \multicolumn{4}{|c|}{ Table 1. Descriptive Statistics } \\
\hline & $\begin{array}{l}\text { Mexican-Origin } \\
\text { Female }\end{array}$ & \multicolumn{2}{|c|}{ White } \\
\hline Unstable active (\%) & 25.9 & 17.1 & 14.3 \\
\hline Stable active (\%) & 74.1 & 82.9 & 85.7 \\
\hline $\begin{array}{l}\text { Stable active } \\
\text { Mean annual earnings } \\
\text { (s.d.) }\end{array}$ & $\begin{array}{l}\$ 19,286 \\
(12,248)\end{array}$ & $\begin{array}{l}\$ 26,517 \\
(18,674)\end{array}$ & $\begin{array}{l}\$ 38,306 \\
(24,111)\end{array}$ \\
\hline $\begin{array}{l}\text { Unstable active } \\
\text { Mean annual earnings } \\
\text { (s.d.) }\end{array}$ & $\begin{array}{l}\$ 6,627 \\
(6,318)\end{array}$ & $\begin{array}{r}\$ 9,949 \\
(11,873)\end{array}$ & $\begin{array}{l}\$ 14,802 \\
(15,269)\end{array}$ \\
\hline $\begin{array}{l}\text { Mean age } \\
\text { (s.d.) }\end{array}$ & $\begin{array}{c}34.65 \\
(10.62)\end{array}$ & $\begin{array}{c}37.09 \\
(12.47)\end{array}$ & $\begin{array}{c}38.31 \\
(12.03)\end{array}$ \\
\hline $\begin{array}{l}\text { Education }(\%) \\
\leq 12 \text { years } \\
\text { High school diploma } \\
\text { Some college } \\
\geq \text { College degree }\end{array}$ & $\begin{array}{r}38.2 \\
30.9 \\
22.7 \\
8.3\end{array}$ & $\begin{array}{r}9.6 \\
32.9 \\
31.8 \\
25.7\end{array}$ & $\begin{array}{l}11.5 \\
32.0 \\
27.8 \\
28.7\end{array}$ \\
\hline $\begin{array}{l}\text { Nativity Status (\%) } \\
\text { Foreign-born } \\
\text { Native-born }\end{array}$ & $\begin{array}{l}43.3 \\
56.7\end{array}$ & $\begin{array}{r}4.0 \\
96.0\end{array}$ & $\begin{array}{r}7.6 \\
92.4\end{array}$ \\
\hline $\begin{array}{l}\text { Currently married, (\%) } \\
\text { spouse present } \\
\text { Economic sectors }(\%)\end{array}$ & 53.0 & 59.0 & 68.1 \\
\hline Core transformative & 11.6 & 9.9 & 30.6 \\
\hline Core services & 15.3 & 20.8 & 23.1 \\
\hline Periphery transformative & 6.4 & 2.4 & 4.2 \\
\hline Periphery services & 63.2 & 65.0 & 37.4 \\
\hline Extractive & 3.4 & 1.8 & 4.7 \\
\hline $\mathbf{N}$ & 1,399 & 17,092 & 24,440 \\
\hline
\end{tabular}

Among stably employed workers, Mexican-origin women had the lowest mean annual earnings among the three ethnic/gender groups. Mexican-origin women earned 50\% as much as White men (Avalos, 1996). Compared to White women, Mexican-origin women earned about $73 \notin$ to the dollar. Among unstably employed women, Mexicans earned $67 \%$ as much as their White counterparts. Earnings inequality for unstably employed Mexican-origin women is even more pronounced when compared to unstably employed White men. Mexican- origin women earned $45 \%$ as much as White men. The earnings of Mexican-origin women are the most adversely affected of all gender and ethnic groups.

Table 1 also confirms that Mexican-origin women tend to be younger than White workers. Although the data revealed that the educational gap between Mexican-origin women and Whites persists, women of Mexican descent in the work force seem to be nearing parity with Whites in terms of high school graduation rates. At all other schooling levels, underachievement prevailed. For example, compared to White women, there were almost four times as many Mexican-origin women with 12 or less years of schooling. At the other end of the educational distribution, Mexican-origin women with at least a college degree were severely underrepresented $(8.3 \%)$ relative to White women $(25.7 \%)$ and White men $(28.7 \%)$.

In terms of marital status, a lower proportion of Mexican-origin women who were married and living with their spouses were active in the work force relative to White women: $53 \%$ versus $59 \%$, respectively. In contrast, fully $68 \%$ of White men were in the same marital status. These differences reflect the stronger child care and other household pressures on married Mexican women that still keeps a larger percentage out of the labor force than is the case for married White women and men.

Of the Mexican-origin women in the labor force, about $43 \%$ were immigrants. This reflects recent changes in the immigrant composition of the labor force of Mexican descent in the United States.

The distribution of women by economic sector was also highly skewed when compared to men's distribution. Women were heavily concentrated in the periphery sector. Nearly two-thirds of Mexican-origin women (63.2\%) and White women (65.0\%) were employed in the periphery services sector, whereas a little more than onethird of White men (37.4\%) were similarly employed. Employment in the periphery services sector is less desirable than in the core services sector, because it offers less than average wages; it also tends to provide less stable employment. The employment of Mexican-origin women in the core transformative sector (11.6\%) was slightly higher than their White counterparts (9.9\%). Core transformative sector employment is desirable because it offers better-than-average wages, but the risk of joblessness is high. Historically, women of Mexican descent have been active to a greater extent than White women in manufacturing and agricultural production 
(Barrera, 1979; Bean and Tienda, 1987). The results presented show that this pattern persists. Lastly, Mexicanorigin women were underrepresented in the core services sector $(15.3 \%)$ relative White women $(20.8 \%)$.

\section{Determinants of Employment Instability}

Table 2 presents the logistic regression results predicting employment instability separately for Mexican-origin women and White women and White men. The dependent variable is a dichotomous discrete variable: employment instability versus employment stability. As hypothesized, the results show that Mexican-

\begin{tabular}{|c|c|c|c|}
\hline \multicolumn{4}{|c|}{$\begin{array}{c}\text { Table 2. Logistic Regression Models P } \\
\text { Employment Instability }\end{array}$} \\
\hline & Mexican-Origin & \multicolumn{2}{|c|}{ White } \\
\hline & Female & Female & Male \\
\hline \multirow[t]{2}{*}{ Age } & $-0.1470^{* * *}$ & $-0.1641 * * *$ & $-0.1991 * * *$ \\
\hline & $(0.0390)$ & $(0.0106)$ & $(0.0094)$ \\
\hline \multirow[t]{2}{*}{ Agesq } & $0.00142 * * *$ & $0.00170^{* * *}$ & $0.00213^{* * *}$ \\
\hline & $(0.00051)$ & $(0.00014)$ & $(0.00012)$ \\
\hline \multicolumn{4}{|l|}{ Education } \\
\hline \multirow[t]{2}{*}{$\leq 12$ years } & $1.9593^{* * *}$ & $1.1302 * * *$ & $1.1955^{* * *}$ \\
\hline & $(0.3563)$ & $(0.0727)$ & $(0.0602)$ \\
\hline \multirow[t]{2}{*}{ High school diploma } & $1.1486^{* * * *}$ & $0.4780 * * *$ & $0.5550 * * *$ \\
\hline & $(0.3572)$ & $(0.0517)$ & $(0.0479)$ \\
\hline \multirow[t]{2}{*}{ Some college } & $1.1157 * * *$ & $0.4912 * * *$ & $0.4514 * * *$ \\
\hline & $(0.3667)$ & $(0.0520)$ & $(0.0502)$ \\
\hline$\geq$ College degree [reference] & --.--- & --.--- & --.--- \\
\hline \multicolumn{4}{|l|}{ Nativity Status } \\
\hline Foreign-born & $0.3465^{*}$ & $0.2056^{*}$ & 0.0877 \\
\hline Native-born [reference] & --.--- &.----- &.----- \\
\hline \multirow{2}{*}{$\begin{array}{l}\text { Currently married, } \\
\text { spouse present }\end{array}$} & -0.0975 & $-0.3268 * * *$ & $-0.7144 * * *$ \\
\hline & $(0.1371)$ & $(0.0389)$ & $(0.0367)$ \\
\hline \multicolumn{4}{|l|}{ Economic sectors } \\
\hline \multirow[t]{2}{*}{ Core transformative } & 0.4998 & $0.3406^{* * *}$ & $0.6450 * * *$ \\
\hline & $(0.3728)$ & $(0.0734)$ & $(0.0541)$ \\
\hline Core services [reference] & --.--- & --.--- &.----- \\
\hline \multirow[t]{2}{*}{ Periphery transformative } & -0.7390 & $0.6113^{* * *}$ & 0.1377 \\
\hline & $(0.3784)$ & $(0.1120)$ & $(0.0988)$ \\
\hline \multirow[t]{2}{*}{ Periphery services } & $0.7215^{* * *}$ & $0.8210 * * *$ & $0.6406^{* * *}$ \\
\hline & $(0.2123)$ & $(0.0520)$ & $(0.0522)$ \\
\hline \multirow[t]{2}{*}{ Extractive } & $1.7538^{* * *}$ & $0.6378^{* * *}$ & $0.5848^{* * * *}$ \\
\hline & $(0.3661)$ & $(0.1682)$ & $(0.0889)$ \\
\hline \multirow[t]{2}{*}{ Intercept } & 0.1687 & $1.1264 * * *$ & $1.8387 * * *$ \\
\hline & $(0.8008)$ & $(0.2054)$ & $(0.1838)$ \\
\hline \multirow{2}{*}{$\begin{array}{l}-2 \text { Log Likelihood } \\
\text { N }\end{array}$} & $1,421.2$ & 750.6 & 966.2 \\
\hline & 1,399 & 992 & 440 \\
\hline
\end{tabular}

origin women who are young, poorly educated, immigrants and employed in the periphery, or extractive sectors are highly likely to be unstably employed.

The results also show that age attenuates the likelihood of employment instability, but the effect is stronger for White women and White men than for Mexican-origin women. Since women of Mexican descent are more prone to interruptions in employment than the other two groups, the age effect is weaker as the respondent gets older. This indicates that the negative effect of work interruptions accumulate over time.

In terms of schooling, Mexican-origin women with 12 or less years of schooling were highly vulnerable to employment instability. They were seven times $\left(\mathrm{e}^{1.9593}=\right.$ 7.07) as likely to be unstably employed compared to their co-ethnics with at least a college degree. In contrast, similarly educated White women and White men were less than half as likely as Mexican-origin women to experience employment instability $\left(\mathrm{e}^{1.1302}=3.1\right.$ and $\mathrm{e}^{1.1955}=$ 3.3, respectively). Although a high school diploma substantially reduced the risk of employment instability for Mexican-origin women, they were nonetheless more susceptible to employment instability than their White male and female counterparts. Surprisingly, the attainment of some college education did not significantly reduce the likelihood of employment instability for Mexican-origin women, White women, or White men.

However, Mexican-origin women who had some college education seem to be the ones to gain the most. For them, the likelihood of employment instability was reduced by about $20 \%$ relative to their peers with only a high school diploma. ${ }^{2}$

The coefficient for Mexican immigrant women was statistically significant. Mexican immigrant women were more susceptible to experience interruptions in employment compared to their U.S.-born peers. Whereas White women and White men who were married and lived with their spouses were less likely to be unstably employed, the coefficient for women of Mexican descent was not statistically significant.

As anticipated, Mexican-origin women employed in the periphery sector were twice as likely as their peers in the core services sector to experience employment instability. This confirms that employment in the extractive sector renders women of Mexican descent highly vulnerable to employment instability. Workers in the core and periphery transformative sectors were 
expected to be susceptible to employment instability. This is true for White women, but not for Mexican-origin women. The corresponding coefficients for Mexicanorigin women were not statistically significant, whereas for White women they were significant. For White men, the core transformative sector is significant. While White women and White men have a position advantage by being employed in the core services sector, Mexicanorigin women do not seem to be protected from employment instability to the same degree.

\section{Employment Instability's Earnings Consequences}

Table 3 shows the results for the earnings determination model for Mexican-origin women and White women and White men. The dependent variable is the natural logarithm of annual earnings. The results contained in this table support the hypothesis that employment instability exerted a penalty on women's annual earnings. Unstable employment in the labor market severely depressed the earnings of Mexicanorigin women. They earned only $32 \%$ as much as their stably employed peers. ${ }^{3}$ Similarly, White women who experienced employment instability earned $34 \%$ as much as their stably employed peers. In contrast, White males who were unstably employed earned $38 \%$ as much as their adequately employed counterparts.

The results also indicate that the differential rate of returns to age, a proxy for labor market experience, had a lower positive effect on earnings of Mexican-origin women compared to White women and White men. For example, while the return for each additional year of age brought a $7.9 \%$ advantage to Mexican-origin women, the advantage for White women was $8.5 \%$, and $9.3 \%$ for White men. ${ }^{4}$ The returns to education increase with higher levels of attainment, albeit at a lower rate for Mexican-origin women compared to White women and White men. Unexpectedly, a high school diploma brought a 38\% earnings advantage to Mexican-origin women, whereas a lower return accrued to White women, $33 \%$. The earnings returns for White men with a high school diploma were higher at $42 \%$. Relative to Whites, Mexican-origin women also benefitted economically from having some college education, but the degree did not benefit Mexican-origin women to the same extent as White women and White men.

The annual earnings of immigrant women were depressed relative to their U.S.-born peers. The logistic regression results also showed that Mexican immigrant women were more prone to employment instability than their peers born in the United States.

\begin{tabular}{|c|c|c|c|}
\hline \multicolumn{4}{|c|}{$\begin{array}{c}\text { Table 3. Linear Regression Models of the } \\
\text { Logarithm of Annual Earnings }\end{array}$} \\
\hline & \multirow{2}{*}{$\begin{array}{c}\text { Mexican-Origin } \\
\text { Female }\end{array}$} & \multicolumn{2}{|c|}{ White } \\
\hline & & Female & Male \\
\hline Unstable active & $\begin{array}{l}-1.1430 * * * \\
(0.0506)\end{array}$ & $\begin{array}{l}-1.085^{* * *} \\
(0.0182)\end{array}$ & $\begin{array}{l}-0.9708 * * * \\
(0.0163)\end{array}$ \\
\hline Age & $\begin{array}{l}0.0762 * * * \\
(0.0128)\end{array}$ & $\begin{array}{l}0.0816 * * * \\
(0.0041)\end{array}$ & $\begin{array}{l}0.0888 * * * \\
(0.0035)\end{array}$ \\
\hline Agesq & $\begin{array}{l}-0.0008 * * * \\
(0.0001)\end{array}$ & $\begin{array}{l}-0.0009 * * * \\
(0.00005)\end{array}$ & $\begin{array}{l}-0.0009 * * * \\
(0.00004)\end{array}$ \\
\hline \multicolumn{4}{|l|}{ Education } \\
\hline$\leq 12$ years[omitted] & --.-- & --.-- & --.-- \\
\hline High school diploma & $\begin{array}{l}0.3217 * * * \\
(0.0549)\end{array}$ & $\begin{array}{l}0.2843 * * * \\
(0.0285)\end{array}$ & $\begin{array}{l}0.3479 \text { *** } \\
(0.0210)\end{array}$ \\
\hline Some college & $\begin{array}{l}0.5192 * * * \\
(0.0617)\end{array}$ & $\begin{array}{l}0.4421 * * * \\
(0.0289)\end{array}$ & $\begin{array}{l}0.4443 * * * \\
(0.0217)\end{array}$ \\
\hline$\geq$ College degree & $\begin{array}{l}0.7542 * * * \\
(0.0811)\end{array}$ & $\begin{array}{l}0.8873 * * * \\
(0.0296)\end{array}$ & $\begin{array}{l}0.7871 * * * \\
(0.0219)\end{array}$ \\
\hline \multicolumn{4}{|l|}{ Nativity Status } \\
\hline Foreign-born & $\begin{array}{l}-0.1157 * \\
(0.0490)\end{array}$ & $\begin{array}{c}0.0170 \\
(0.0379)\end{array}$ & $\begin{array}{l}-0.0204 \\
(0.0306)\end{array}$ \\
\hline Native-born [omitted] & --.-- & --.-- & --.-- \\
\hline $\begin{array}{l}\text { Currently married, } \\
\text { spouse present }\end{array}$ & $\begin{array}{c}0.0763 \\
(0.0429)\end{array}$ & $\begin{array}{l}-0.056 * * * \\
(0.0140)\end{array}$ & $\begin{array}{l}0.2455^{* * *} \\
(0.0127)\end{array}$ \\
\hline \multicolumn{4}{|l|}{ Economic sectors } \\
\hline Core transformative & $\begin{array}{l}0.3491 * * * \\
(0.0662)\end{array}$ & $\begin{array}{l}0.2901 * * * \\
(0.0210)\end{array}$ & $\begin{array}{l}0.2858 * * * \\
(0.0135)\end{array}$ \\
\hline Core services & $\begin{array}{l}0.2458 * * * \\
(0.0582)\end{array}$ & $\begin{array}{l}0.2575 * * * \\
(0.0161)\end{array}$ & $\begin{array}{l}0.2957 * * * \\
(0.0147)\end{array}$ \\
\hline Periphery transformative & $\begin{array}{c}0.1255 \\
(0.0851)\end{array}$ & $\begin{array}{c}0.0932 * \\
(0.0395)\end{array}$ & $\begin{array}{l}0.1474 * * * \\
(0.0283)\end{array}$ \\
\hline Periphery services [omitted] &.---- & --.-- & --.-- \\
\hline Extractive & $\begin{array}{l}-0.2729 * \\
(0.1166)\end{array}$ & $\begin{array}{l}-0.651 * * * \\
(0.0599)\end{array}$ & $\begin{array}{l}-0.3331 * * * \\
(0.0280)\end{array}$ \\
\hline Intercept & $\begin{array}{l}7.7187 * * * \\
(0.2325)\end{array}$ & $\begin{array}{l}7.7187 * * * \\
(0.0790)\end{array}$ & $\begin{array}{l}7.5900^{* * *} \\
(0.0665)\end{array}$ \\
\hline $\mathbf{R}^{2}$ & 0.4618 & 0.3306 & 0.3556 \\
\hline $\mathbf{N}$ & 1,399 & 17,092 & 24,440 \\
\hline Note: $* \mathrm{p}<.05 * * \mathrm{p}<.01 * * * \mathrm{p}<.0$ & & & \\
\hline
\end{tabular}

Surprisingly, the earnings of married Mexican-origin women living with their spouses were positive, although marginally significant. This contrasts sharply with the depressed earnings of married White women. As anticipated, the earnings of married White men living with their wives were positive compared to their unmarried peers.

The results also show that employment in core-like sectors produces an earnings advantage for workers. Mexican-origin women employed in the core transformative sector earned almost $42 \%$ more than their peers employed in the periphery services sector. This earnings premium is substantially higher than the earnings for White women and White men similarly employed. However, the earnings of Mexican-origin women in core services employment are not as high as 
that of others. Periphery transformative sector employment provides Whites with a wage premium, which does not accrue to Mexican-origin women. Not surprisingly, employment in the extractive sector is economically deleterious to all workers.

\section{Summary and Discussion}

This study compared the extent, causes and earnings consequences of employment instability among Mexican-origin women, White women and White men. The results unequivocally showed that the prevalence of employment instability is higher for women of Mexican descent than White women and White men. The multivariate analysis suggest that Mexican-origin women's vulnerability to employment instability is due, in great measure, to their low human capital endowments and employment in the periphery services sector and extractive sector. The data also revealed that employment instability has deleterious economic consequences; on average, unstably employed workers earn less than their stably employed counterparts.

\section{What are some of the implications of these findings?}

From a policy perspective, the results support efforts to raise the level of schooling for Mexican-origin women. But they also reveal that the returns to schooling for Mexican women are mixed. Education shields Mexicanorigin women from the risk of employment instability, but not to the same degree that it protects White women and White men. On the other hand, compared to White women, the earnings returns to education for Mexican women are favorable, except for Mexican women with a college degree. This suggests that education might not command the same value for Mexican and White women in the labor market. Future studies should examine whether the quality of Mexican women's education is objectively lower relative to their White counterparts, or whether employers doubt that Latinas have mastered the same skills as their White counterparts. If the quality of education of Mexican women is indeed inferior, then educational policy should address this issue. On the other hand, if employers are subjectively evaluating Mexican women's education as inferior, then policy makers should redouble efforts to enforce anti-discrimination laws.
According to projected occupational changes among Mexican-origin women, some occupations will experience a declining demand in the next few years (e.g., private household cleaners, servants and sewing machine operators), while others will experience a demand increase (e.g., retail and sales workers, nursing aides, janitors, cooks and bookkeepers). Unfortunately, the occupations expected to grow command low earnings, require little training and tend to be unstable jobs (Department of Labor, 1997). These are "bad" jobs located in the periphery services sector of the economy. Mexican women need access to increased education and job skills training, but especially skills that will secure them "good," stable jobs.

The effect of employment instability on families headed by women should also be a concern of future research. Recent data revealed that, between 1985 and 1995, the number of Latina families maintained by women grew by $64 \%$ (905,000 to 1.5 million). Today, fully one-quarter of Latino families are maintained by women. The average family size is between three and four persons (Department of Labor, 1997).

As this study showed, unstably employed Mexicanorigin women had annual average earnings of $\$ 6,627$, which is less than half the poverty threshold for a family of four (\$15,569 in 1994). If unstably employed Mexican women are heads of households and have children to support, then surely they and their children face severe economic hardship.

The current national reform of the welfare system is aimed at reducing poverty by forcing welfare recipients to work or lose benefits. Given this direction in welfare policy, it is more important than ever to understand whether available jobs can realistically keep individuals and their families out of poverty. Indeed, research shows that, while work is clearly important for women of Mexican origin, employment is not always "stable enough" to provide workers with an adequate income.

In sum, this study shows that employment instability is a nontrivial issue.

Employment instability is further intensified given racial/ethnic stratification among women in the labor market. And, as more Mexican-origin women enter the work force, research that contributes to the understanding of the economic inequality of available jobs - specially unstable jobs - becomes even more critical. 


\section{Endnotes}

1. The following firms are typically found in Tigges (1987) typology of economic sectors: core transformative - automobile industry; core services banking and finance; periphery transformative apparel industry; periphery services - personal services, hotels; extractive: agriculture.

2. The odds ratio for Mexican-origin women with some college education is $\mathrm{e}^{1.1527}=3.0$, versus $\mathrm{e}^{1.1486}=3.2$ for their peers with only a high school diploma.

3. The percentage is calculated by taking the anti-log of the unstable active coefficient; thus, for Mexicanorigin women, $32 \%=\mathrm{e}^{-1.1430} \times 100$. The same procedure is used for the other groups.

4. This is obtained for Mexican-origin women as $7.9 \%$ $=\left(1-\mathrm{e}^{0.0762}\right) \times 100$, and denotes the percentage increase in the odds based on a discrete, unit increase in the independent variable. The same procedure is used for the other groups.

\section{References}

Avalos, Manuel. 1996. "Gender Inequality: Sorting Out the Effects of Race/Ethnicity and Gender in the Anglo Male-Latino Female Earnings Gap." Sociological Perspectives, 39:497-515.

Barrera, Mario. 1979. Race and Class in the Southwest: A Theory of Racial Inequality. South Bend, Ind.: Notre Dame University Press.

Bean, Frank D. and Marta Tienda. 1987. The Hispanic Population of the United States. New York: Russell Sage Foundation.

Becker, Gary S. 1975. Human Capital. 2nd. edition. New York: Columbia University Press.

Blau, Peter M. and O. Duncan. 1967. The American Occupational Structure. New York: Wiley.

Clark, Kim B. and Lawrence H. Summers. 1979. "Labor Market Dynamics and Unemployment: A Reconsideration." Brookings Papers on Economic Activity, 1:13-60.

Clogg, Clifford C. 1979. Measuring Underemployment: Demographic Indicators for the U.S. New York: Academic Press.
Clogg, Clifford C., Teresa Sullivan, and Jan E. Mutchler. 1986. "Measuring Underemployment and Inequality in the Work Force." Social Indicators Research, $18: 117-52$.

Clogg, Clifford C., Scott Eliason, and Robert Wahl. 1990. "Labor-Market Experiences and Labor-Market Outcomes." American Journal of Sociology, 95:15361576.

De Anda, Roberto M. 1991. "Inequality at Work: A Comparison of Underemployment and Stratification between Mexican-Origin and White Workers." Unpublished Ph.D. dissertation. Tucson: University of Arizona.

De Anda, Roberto M. 1992. "Involuntary Part-Time Work Among Chicanos: Its Causes and Consequences." Pp. 69-87 in Chicano Discourse, edited by T. Mindiola and E. Zamora. Houston, Texas: Mexican American Studies Program, University of Houston.

De Anda, Roberto M. 1994. "Unemployment and Underemployment among Mexican-Origin Workers." Hispanic Journal of Behavioral Sciences, 16:163-75.

De Anda, Roberto M. 1998. "Employment Instability and Earnings of Mexican-Origin Men." Hispanic Journal of Behavioral Sciences, 20(3):364-75.

DeFreitas, Gregory. 1991. Inequality at Work: Hispanics in the U.S. Labor Force. New York: Oxford University Press.

Featherman, David and Robert Hauser. 1978. Opportunity and Change. New York: Academic.

Hsueh, Sheri and Marta Tienda. 1995. "Earnings Consequences of Employment Instability Among Minority Men." In Research in Social Stratification and Mobility, edited by M. Wallace, 39-69. Greenwich, Conn.: Jai Press.

Hsueh, Sheri and Marta Tienda. 1996. "Gender, Ethnicity, and Labor Force Inequality." Social Science Research, 25:73-94.

Lichter, Daniel T. and Nancy S. Landale. 1995. "Parental Work, Family Structure, and Poverty among Latino Children." Journal of Marriage and the Family, 56:633-645. 
Morales, Rebecca and Frank Bonilla. 1993. "Restructuring and the New Economy." In Latinos in a Changing U.S. Economy: Comparative Perspectives on Growing Inequality, edited by R. Morales and Frank Bonilla, 1-27. Newbury Park, Calif.: Sage.

Piore, Michael. 1979. Birds of Passage: Migrant Labor and Industrial Society. Cambridge: Cambridge University Press.

Polachek, Solomon W. and W. Stanley Siebert. 1993. "Gender in the Labour Market." In The Economics of Earnings, edited by S.W. Polachek and W.S. Siebert. Cambridge: Cambridge University Press.

Portes, Alendro, and Robert L. Bach. 1985. Latin Journey: Cuban and Mexican Immigrants in the United States. Berkeley: University of California Press.

Sullivan, Teresa. 1978. Marginal Workers, Marginal Jobs: The Underutilization of American Workers. Austin: The University of Texas Press.
Tienda, Marta and Haya Stier. 1996. "Generating Labor Market Inequality: Employment Opportunities and the Accumulation of Disadvantage." Social Problems, 43:147-165.

Tigges, Leann M. 1987. Changing Fortunes: Industrial Sectors and Workers'Earnings. New York: Praeger.

Tilly, Chris. 1996. Half a Job: Bad and Good Part-Time Jobs in a Changing Labor Market. Philadelphia: Temple University Press.

U.S. Bureau of the Census. 1995. "Current Population Survey: Annual Demographic File, 1995." [MRDF]. ICPSR version. Washington, D.C.: U.S. Bureau of the Census (producer). Ann Arbor, Mich.: InterUniversity Consortium for Political and Social Research (distributor).

U.S. Department of Labor, Women's Bureau. 1997. "Facts on Working Women.” No. 97-2. Washington, D.C. 